\title{
Een bronnenpublikatie als signaal van koloniaal trauma? Ontstaan en ontvangst van de Officiële bescheiden
}

\section{ELSBETH LOCHER-SCHOLTEN}

De jaren 1940-1950 vormen met Duitse bezetting en Indonesische revolutie het meest traumatische decennium uit de geschiedenis van Nederland in de twintigste eeuw. Beide processen delen die tien jaar eerlijk in tweeën, maar afgezien van die mathematische overeenkomst is er weinig gelijkenis. Exemplarisch is bijvoorbeeld het grote verschil tussen de zonnige 5e mei 1945, dag van bevrijding en publieke vreugde, en de druilerige 27 december 1949, dag van de stemmige souvereiniteitsoverdracht vol officiële ernst.

Kennis over en benadering van beide perioden lopen in Nederland navenant uiteen. Het publiek kent over het algemeen de veertien dikke delen van L. de Jong, Het koninkrijk der Nederlanden in de tweede wereldoorlog, nu zelfs in pocket verkrijgbaar. Weinigen echter zijn op de hoogte van het bestaan van de Officiële bescheiden betreffende de Nederlands-Indonesische betrekkingen 1945-1950, de twintig-delige bronnenpublikatie van S. L. van der Wal, P. J. Drooglever en M. J. B. Schouten. Nog minder mensen hebben hun inhoud: 15.000 bladzijden stukken, geselecteerd uit meer dan $2 \mathrm{~km}$ archief, ooit bekeken ${ }^{2}$. Het verschil in populariteit van beide series, beide uitvloeisel van een regeringsopdracht, kan niet groter zijn. De geschiedenis van de jaren 1940-1945 leeft, die van de daaropvolgende periode van dekolonisatie was tot voor kort onbekend en weinig bemind.

De vergelijking roept verschillende vragen op. Ten eerste naar het verschil in historische presentatie: waarom een toegankelijke, verhalende serie voor de jaren '40-'45 en een 'moeilijke' bronnenpublikatie voor de periode '45-'50? Wat zegt de keuze voor die vorm over de manier waarop in Nederland met het koloniale verleden is omgegaan? Ten tweede: wat onthullen ontstaan en ontvangst van de Officiële bescheiden over de publieke herinnering aan de periode 1945-1950 of- om in de gangbare psychologische termen te spreken - over de verwerking van koloniaal trauma? En ten derde, welke rol hebben de verschillende belanghebbende 'beroepsgroepen', historici, regering, politiek en pers in dat proces gespeeld? Gezien de hef-

1 Vrij naar Monika van Paemel, 'Tussen Parijs en Amsterdam', De Gids, CLV ( 1992) 224.

2 Officiële bescheiden betreffende de Nederlands-Indonesische betrekkingen 1945-1950 (19 dln; 's- Gravenhage, 1971 -1994); I t/m VIII ( 1971 -1979) uitgegeven door S. L. van der Wal; IX ( 1981 ) uitgegeven door S. L. van der Wal, voltooid door P. J. Drooglever en M. J. B. Schouten; X-XIX ( 1982-1994) uitgegeven door P. J. Drooglever en M. J. B. Schouten. 
tige publieke discussie over de periode 1945-1950 van de laatste jaren en omdat dit onderwerp nu ook deel uitmaakt van de voorgestelde eindtermen van het havo/vwo eindexamen geschiedenis, zijn dat mijns inziens relevante vragen ${ }^{3}$.

\section{Voorgeschiedenis}

Op vrijdag 17 januari 1969 sprak dr. J. Hueting op de tv over Nederlandse oorlogsmisdaden in Indonesië. De schok was intens. In een periode dat het morele gehalte van vele buitenlanden de Nederlandse publieke opinie over die landen bepaalde, bleek Nederland zelf niet waardenvast. De Tweede Kamer vroeg de regering enkele dagen later om nadere gegevens. Het confessioneel-liberale kabinet-De Jong reageerde onmiddellijk. Behalve een toezegging van nader onderzoek over de 'wandaden' van Nederlandse militairen zelf, verleende het op 28 januari de rijkscommissie voor de vaderlandse geschiedenis (waarover dadelijk meer) een formele opdracht tot het uitgeven van officiële bescheiden betreffende de Nederlands-Indonesische betrekkingen 1945-1950. Reeds een dag later aanvaardde de rijkscommissie die opdracht ${ }^{4}$.

Uit die snelle reactie blijkt wel, dat de rijkscommissie niet werd overvallen. Historici plegen niet over één nacht ijs te gaan; hun tijdsbesef is er een van de langere duur. Het optreden van Hueting heeft het proces wel versneld, maar aan de officiële opdracht was al een periode van twaalf jaar voorgeschiedenis voorafgegaan. Die voorgeschiedenis illustreert op markante wijze het proces van verdringing van de dekolonisatie in de jaren vijftig en zestig; het geeft aan hoe dat proces van zwijgen over het koloniale verleden verliep en verklaart waarom het tenslotte toch tot een bronnenpublikatie kwam. Wetenschapsgeschiedenis, het ontstaan van een bronnenpublikatie, was in dit geval politieke geschiedenis.

Waar het de Nederlandse belangstelling voor het koloniale verleden betrof, zijn de jaren vijftig en zestig zeker te karakteriseren als een periode van verdringing van verlies, als tijd van grote stilte ${ }^{5}$. Terwijl het Rijksinstituut voor oorlogsdocumentatie (RIOD) al op 8 mei 1945 begon materiaal te verzamelen over de oorlogsjaren, in 1955 gevolgd door de officiële opdracht tot geschiedschrijving aan dr. L. de Jong, bleef de belangstelling voor de periode 1945-1950 gering. Niemand achtte het nodig om hiervoor enkele dagen na de souvereiniteitsoverdracht een instituut op te richten. De historische literatuur over het onderwerp bleef beperkt: rond 1950 verschenen in Nederland slechts enkele publikaties ${ }^{6}$. Amerikaanse onderzoekers namen de geschiedschrijving over.

3 Stuurgroep Profiel Tweede Fase, Advies examenprogramma's havo en vwo. Geschiedenis en staatsinrichting, aardrijkskunde, maatschappijleer (Den Haag, 1995) 30, 55.

4 Officiële bescheiden, I, v.

5 E. Locher-Scholten, 'Verwerking en koloniaal trauma. Balans van begrippen', Bzzllletin, 228 (sept. $1995) 6$.

6 Bijvoorbeeld H. J. van Mook, Nederland, Indonesië en de wereld (Amsterdam, 1949); C. Smit, De Indonesische quaestie. De wordingsgeschiedenis van de souvereiniteitsoverdracht (Leiden, 1952). 
Het gebrek aan belangstelling bleek ook bij de opheffing van de parlementaire enquête commissie (PEC) in december 1956. De commissie was in 1948 ingesteld met het doel het regeringsbeleid van de verschillende kabinetten over de periode 10 mei 1940 tot 20 november 1945 alsnog parlementair te toetsen. In 1955 meende zij een beoordeling van dat beleid niet langer te mogen baseren op enquêtes over gebeurtenissen die voor een deel langer dan vijftien jaar terug hadden plaatsgevonden. In deel acht had zij enige aandacht besteed aan de militaire terugkeer van het Nederlands gezag in Nederlands-Indië na augustus 1945. Het algemene beleid ten opzichte van de overzeese gebiedsdelen was echter een van de weinige punten, die waren blijven liggen. De Kamer ging evenwel ondanks protest van uiterst rechts en uiterst links akkoord met het voorstel tot opheffing ${ }^{7}$.

Het verscheiden van de parlementaire enquête commissie vormde de aanzet tot eerste concrete pogingen om tot historisch onderzoek naar de periode 1945-1950 te komen. Eerdere plannen waren niet gerealiseerd ${ }^{8}$. Het initiatief kwam in februari 1957 van historici, en wel van het bestuur van het RIOD, dat hiertoe was geïnspireerd door prof. dr. I. J. Brugmans. Brugmans was als participant - hij was van 1929 tot 1946 Indisch ambtenaar, vervolgens hoogleraar aan de letteren-faculteit te Batavia geweest - en als historicus dubbel bij het koloniale verleden betrokken. Behalve hoogleraar economische geschiedenis aan de universiteit van Amsterdam, was hij in 1957 ook voorzitter van de stichting 'Indië in de tweede wereldoorlog', de vorm waarin de Indische afdeling van het RIOD op dat moment opereerde ${ }^{9}$. Brugmans kan worden aangemerkt als de auctor intellectualis van de latere bronnenpublikatie. Op zijn suggestie stelde het RIOD-bestuur de minister van onderwijs, kunsten en wetenschappen, J. L. M. Th. Cals, in februari 1957 voor om, nu de parlementaire enquête commissie was opgeheven, onderzoek te doen naar het beleid der regering inzake Nederlands-Indië in de periode 1945-1950, 'een complex van gebeurtenissen van uitzonderlijk belang ${ }^{10}$. Voorzichtig voegde het bestuur er aan toe dat de regering dan alsnog zou kunnen beslissen of zij het manuscript, dat in vijfjaar voltooid zou moeten zijn, zou willen publiceren of niet.

Over de vraag van het RIOD-bestuur won de minister het advies in van de rijkscommissie voor de vaderlandse geschiedenis. Deze commissie van hoogleraren en

7 Handelingen Staten-Generaal, TweedeKamer 1956-1957,458-468,Bijlage4561.P.S.Gerbrandy en Ch. J. I. M. Welter maakten bezwaar tegen opheffing vanuit de veronderstelling dat de PEC de verantwoordelijken voor 'de liquidatie van het Koninkrijk' zoals W. Schermerhom c. s. had willen sparen. W. Gortzak protesteerde, omdat nu niet duidelijk werd waarom het na de 7 decemberrede van koningin Wilhelmina mis was gegaan.

8 H. Baudet, 'Nederland en Indonesië. Overwegingen bij een recente bronnenpublicatie', Tijdschrift voor geschiedenis, LXXXIX (1976) 70.

9 De stichting was in 1952 opgericht om inkomsten uit de 'derde-geldstroom', het Indisch bedrijfsleven te kunnen incasseren ten behoeve van een bronnenpublikatie over Nederlanders in Nederlands-Indië tijdens de Japanse bezetting. In 1957 nam het RIOD de financiële verantwoordelijkheid weer op zich. RIOD, Indische Afdeling, map 46 en 47.

10 Voorzitter directorium RIOD prof. jhr. dr. P. J. van Winter aan minister OKW mr. J. M. L. Th. Cals, 14-2-1957. Archief RIOD, map 1 Ind. 
archivarissen, al sinds 1902 verantwoordelijk voor de groenbandige Rijksgeschiedkundige Publicatiën (RGP), functioneerde tevens als adviesorgaan voor de regering. Zij was snel klaar met haar oordeel; het netwerk was immers klein. De voorzitter van het RIOD-bestuur, prof. jhr. P. J. van Winter, was tevens voorzitter van de rijkscommissie. Uit de notulen van de vergadering van de rijkscommissie blijkt overigens dat het Brugmans, het RIOD en de rijkscommissie zelf niet ging om publikatie van een boek maar om het verzamelen van archiefmateriaal en het houden van interviews met nog levende betrokkenen, in moderner vakjargon oral history. Ondanks het positieve advies van de rijkscommissie wees de minister in november 1957 het verzoek af. Als reden gaf hij 'huidige omstandigheden', de bestedingsbeperking van dat jaar 11 .

In mei en december 1958 kwam de regering echter herhaaldelijk onder druk te staan van leden uit de Eerste Kamer. VVD-woordvoerder Harm van Riel, die deel uitmaakte van de 'historische lobby' - hij kende Brugmans uit het bestuur van het Nederlands-Economisch Archief_- drong aan op materiaalverzameling en interviews. Conform Brugmans en rijkscommissie achtte hij publikatie nog niet aan de orde. De PvdA-ers M. de Niet en J. in 't Veld sloten zich daarbij aan. Onder die druk besloot de regering in november 1958 nogmaals het advies in te winnen van de rijkscommissie. In de ministerraad had premier W. Drees voorzichtig gesteld, dat 'de geschiedenis van de Indonesische kwestie op een of andere manier geschreven moet worden', maar dat hij 'deze werkzaamheden zoveel mogelijk [zou] willen beperken'; een uitspraak die de aarzeling in regeringskring treffend illustreerde ${ }^{12}$.

In februari 1959 herhaalde de rijkscommissie na een uitvoerige discussie haar steun aan het oorspronkelijke voorstel tot verzameling van materiaal. Het had wel enige voeten in de aarde gehad. De secretaris/directeur A. J. Veenendaal had andere prioriteiten dan dit politiek relevante onderzoek; hij was 'niet verlangend' naar uitbreiding van zijn taken, omdat hij vreesde dat zijn werk aan de uitgave-Oldenbarnevelt in het gedrang zou komen. Desondanks besloot de commissie de taak op zich te nemen. Brugmans werd daarom als nieuw lid in de commissie opgenomen ${ }^{13}$.

11 Staatssecretaris OKW aan directorium RIOD, 8-11 -1957, Archief RIOD; notulen rijkscommissie voor de vaderlandse geschiedenis 12-9-1957, Instituut voor Nederlandse geschiedenis (ING); over de rijkscommissie K. Kooijmans en J. P. de Valk, "Eene dienende onderneming'. De rijkscommissie voor vaderlandse geschiedenis en haar bureau 1902-1968', in: Bron en publikatie. Voordrachten en opstellen over de ontsluiting van geschiedkundige bronnen, uitgegeven bij het 75-jarig bestaan van het bureau der rijkscommissie voor vaderlandse geschiedenis ('s-Gravenhage: Bureau RCVG, 1985) 203-271. In 1989 werd de rijkscommissie opgeheven en vervangen door het Instituut voor Nederlandse geschiedenis (ING). Haar adviestaak was daarmee beëindigd.

12 Handelingen Eerste Kamer 1957-1958, 393, 413 (13 mei 1958). Luns noemde het onderzoek in zijn antwoord 'omvangrijk, tijdrovend en kostbaar' en de 'gevoeligheden op internationaal en nationaal vlak en vooral op het laatste' een bezwaar (Ibidem, 430 (14 mei 1958)). Zie <x>k Handelingen Eerste Kamer 1958-1959,46,56 (2 december 1958). Notulen ministerraad 21-11-1958 (ARA). Voor de toezegging van minister Drees aan de Kamer in die richting Handelingen Eerste Kamer, 1958-1959, 73 (3 december 1958).

13 Notulen rijkscommissie, 23-2-1959, 28-9-1959, 28-1-1960, ING. Brugmans was inmiddels ook betrokken bij een andere activiteit van vroegere Indische ambtenaren of anderszins bij Indië geïnteresseerden: 
Maar veel haast maakte de regering niet. Het zou nog een derde ronde kamervragen, een nieuwe regeringstoezegging (nu van minister-president J. E. de Quay), hernieuwd overleg tussen rijkscommissie en regering, en herhaalde besprekingen in de ministerraad over geheimhouding en toezicht kosten, voordat de ministerraad in september 1960 besloot tot het verzamelen van gegevens ${ }^{14}$. Pas in december 1960 tenslotte kon een voormalig Indisch ambtenaar, de oud-resident van Bali en Lombok dr. M. Boon, deze taak aanvaarden. Tijdens de oorlog voor verlof in Nederland was hij in 1943 in Utrecht gepromoveerd bij prof. F. C. Gerretson. Hij was daarmee voor de regering en rijkscommissie een alleszins betrouwbaar onderzoeker. Boon zou materiaal verzamelen uit archieven en interviews houden. Van publikatie zou - daarover waren rijkscommissie, regering en geïnteresseerde leden van de Eerste Kamer het om principiële of tactische redenen volledig eens - geen sprake zijn. Boon werd bovendien gebonden aan stricte geheimhouding ${ }^{15}$.

$\mathrm{Na}$ vier jaar overleg was dus het plan-Brugmans in de steigers gezet. Historici, sommigen met aanwijsbare banden met het vooroorlogse Indië, hadden daartoe het initiatief genomen en positief geadviseerd; zonder politieke druk uit de Eerste Kamer van PvdA en VVD zou de regering, eerst het kabinet-Drees, opgevolgd door het kabinet-De Quay hier niet toe hebben besloten. In 1960, het jaar dat L. de Jong met zijn tv-serie De bezetting begon en de tweede wereldoorlog in de Nederlandse huiskamer presenteerde, ging dus één man in het grootste geheim het materiaal verzamelen, waar een latere geschiedschrijving over de periode '45-'50 van moest profiteren. Het RIOD was toen met ongeveer dertig medewerkers al vijftien jaar lang bezig zijn collectie op te bouwen en bronnen uit te geven. In tegenstelling tot de verhoren van de parlementaire enquête commissie, die onder ede door een commissie hadden plaats gevonden, zou Boon betrokkenen interviewen in de beslotenheid van de studeerkamer zonder de garantie van een eed of gelofte. Geheimhouding was overigens niet alleen een door de regering gestelde eis, maar ook de voorwaarde waaronder Boon gegevens en papieren van betrokkenen bij het dekolonisatieproces zou kunnen verkrijgen, aldus de rijkscommissie.

Voor deze traagheid en voorzichtigheid is een aantal redenen aan te wijzen. Geeen bronnenpublikatie over het koloniale beleid 1900-1942. Deze was opgezet om tegenwicht te bieden tegen 'tendentieuze geschiedschrijving' over Indonesië in het buitenland. Uit dezelfde kring kwam in 1961 ook het evaluerende Balans van beleid uit. De auteurs hadden eerst een geschiedenis door één auteur/ participant op het oog gehad. Toen dat niet lukte, kozen zij de vorm van een bundel (H. Baudet en I. J. Brugmans, Balans van beleid. Terugblik op de laatste halve eeuw van Nederlandsch-Indië (Assen, 1961 ; Baudet aan auteur, 12-6-1996).

14 Handelingen Eerste Kamer, 1959-1960,31 (10-11-1959), 72(11-11-1959). Notulen ministerraad $12-$ 8-1960; 23-9-1960, ARA.

15 Van Winter bijvoorbeeld achtte publikatie niet bij voorbaat uitgesloten, maar vond het 'wenselijk voorlopig geruststellend te spreken' (notulen rijkscommissie 18-1-1960, ING). Boon kwam onder een commissie van toezicht bestaande uit leden van de rijkscommissie, Van Winter en Brugmans, terwijl mr. S. Blom, regeringscommissaris voor Indonesische aangelegenheden, op het ministerie van buitenlandse zaken als toezichthouder zou fungeren (minister van buitenlandse zaken aan minister-president 22-7-1960 en 23-8-1960, bij notulen ministerraad 23-9-1960, ARA). 
heimhouding sloot naadloos aan bij het culturele klimaat van de jaren vijftig, waarin de bestuurlijke elites van de verschillende zuilen de onaantastbaarheid van het gezag verdedigden en door hun respectievelijke achterban met overeenkomstig ontzag werden bejegend. Het koloniaal verleden was bovendien (ook toen al) omstreden verleden. Minister van buitenlandse zaken mr. J. M. A. H. Luns had dat in 1958 nog eens benadrukt. Hij was daar dat jaar naar aanleiding van de uitzetting uit Indonesië van alle daar nog wonende Nederlanders extra mee geconfronteerd. Die exodus - door sommige parlementariërs vergeleken met de effecten van de oorlogsverwoesting in 1940-1945 en de watersnoodramp van 1953 — was voor de PvdA-fractie in de Eerste Kamer aanleiding tot schuldbekentenis, een mea culpa, hetgeen leidde tot een (eerste) schuld-en-boete-debat. De fractie achtte Nederland door het moeizame dekolonisatieproces mede schuldig aan de definitieve breuk tussen beide landen. Daarom diende de regering aanknopingspunten te zoeken voor nieuwe onderhandelingen, ook over het netelige probleem Nieuw-Guinea. Luns kon er zich niet in vinden ${ }^{16}$.

De slechte verhouding met Indonesië in het algemeen en de Nieuw-Guinea-kwestie in het bijzonder stimuleerden Luns, onder wiens departement tal van relevante archieven vielen, ook niet tot openbaarmaking van wat aan die moeizame relatie was voorafgegaan. Hij kon zich daarbij beroepen op de archiefwet, die stelde dat archieven formeel pas na 50 jaar, dus in 1995-1999, open zouden gaan. Argwaan ten aanzien van contemporaine geschiedenis was bovendien een vrij algemeen verschijnsel in deze jaren. Maar terwijl ten aanzien van de tweede wereldoorlog het bezwaar van een te recent verleden zelden werd geopperd, was het een populair argument wanneer het de dekolonisatie van Indonesië betrof. Om die reden had de ministerraad bijvoorbeeld in 1954 op instigatie van minister Luns en minister van binnenlandse zaken L. J. M. Beel aan dr. A. B. C. M. Kortenhorst de toegang tot de archieven geweigerd toen deze voor wetenschappelijke doeleinden daartoe toestemming had gevraagd. Kort daarop had Beel zich ook gekeerd tegen publikatie van het dagboek van dr. W. Schermerhorn, de voorzitter van de commissie-generaal die in 1946-1947 het akkoord van Linggadjati tot stand had gebracht ${ }^{17}$.

Boons opdracht was overigens niet alleen illustratief voor die toen gebruikelijke geheimhouding rond de dekolonisatie, Boon was er ook zelf het slachtoffer van. Hoezeer participanten aan het dekolonisatieproces, zowel binnen de regering als daarbuiten, de stilte handhaafden, blijkt uit zijn eigen onderzoekservaringen. Van de bijna vijftig betrokkenen die hij voor interviews in de eerste helft van de jaren zestig benaderde, reageerde slechts de helft positief. Schermerhorn, R. F. E. M. Romme, toenmalige fractievoorzitter van de KVP, E. M. J. A. Sassen en J. A. Jonkman, beiden voormalige ministers van koloniën, bleken om uiteenlopende redenen niet bereid tot het geven van informatie. Zo weigerde Schermerhorn Boon te ontvangen, omdat hij

16 Handelingen Eerste Kamer, 1957-1958, 3033; 393-437.

17 Notulen ministerraad, 15-11-1954, Algemeen rijksarchief (ARA); W. Schermerhorn, 'Zegel van geheimhouding dient verbroken', NRC, 31-8-1966. 
groter openheid van de regering eiste en omdat hij van Boon, die zich in 1947 tegenstander van de werkzaamheden van de commissie-generaal had betoond, weinig positiefs verwachtte ${ }^{18}$.

Het project-Boon vormde daarbij voor de regering een gemakkelijk wapen om iedere verdere aanval op de gesloten archieven te pareren. Hoewel er reeds in 1958 een dissertatie in Amerika was verschenen over de Hoge-Veluwe-Conferentie, gebaseerd op materiaal uit Amerikaanse en Indonesische archieven, toch vond Luns dit geen reden om de Nederlandse archieven open te stellen. In 1961 sloeg hij een nieuwe aanval op de geheimhouding in de $N R C$ en in de Eerste Kamer van respectievelijk Schermerhorn en Van Riel af door te verwijzen naar het project-Boon en 'gevoeligheden, die zowel op het nationale als het internationale vlak ... nog steeds bestaan'. Behalve PvdA en VVD had zich nu ook de ARP (de antirevolutionaire historicus H. Algra) in de strijd geworpen. Ook Algra maakte deel uit van de 'historische lobby': hij was met Van Riel op dat moment lid van de commissie van bijstand van het RIOD. Van Riel hoopte optimistisch, dat binnen vijf jaar 'het eerste exemplaar in groene band met gouden opdruk' (lees: RGP-deel) aan de minister zou worden aangeboden. Luns dacht daar anders over maar beloofde regeringsoverleg ${ }^{19}$. Er zijn geen aanwijzingen dat dat serieus heeft plaatsgevonden.

\section{Voorbereiding voor bronnenpublikatie}

In 1966 overleed Boon plotseling. In 1965 had hij nog een korte verlenging voor zijn vrijwel afgeronde opdracht gekregen. Zijn dood, de na 1965 sterk verbeterde verhouding tot het Indonesië van Soeharto en het veranderende culturele klimaat van de jaren zestig baanden de weg voor een nieuw offensief voor openbaarheid. Nu waren het de NRC (dr. E. van Raalte en Schermerhorn) en de Tweede Kamer, die zich voor publikatie van bronnen uitspraken. Van Raalte behoorde als historicus en parlementairjournalist eveneens tot de 'historische lobby' ${ }^{20}$. Het waren echter met name vragen uit de Tweede Kamer van de PvdA-er H. Peschar, die minister Luns in oktober 1966 een positieve uitspraak ontlokten. Hij was in beginsel bereid tot publikatie van het door Boon verzamelde, 'voor zover geen overwegingen van landsbelang en belangen, gelegen in de betrekkingen met vreemde mogendheden, zich daartegen zouden blijken te verzetten ${ }^{12}$. De politieke druk kwam nu van meerdere partijen, PvdA,

18 Eindrapport M. Boon, 20-9-1965,4-5, Bijlage A, ING. D. 6. Collectie-Boon; W. Schermerhorn, 'Zegel van geheimhouding dient verbroken', NRC, 31-8-1966.

19 Handelingen Eerste Kamer 1960-1961, Voorlopig Verslag, B. 6100, 111,84,19; Memorie van Antwoord. B 6100, Hl 84a 13; 315-316, 327-333, 339-340, 343. Zie ook 'Dezer Dagen', NRC, 16-1-1961 en 23-11961.

20 Hij stond bekend als een 'lobby-correspondent'; als parlementair deskundige was hij bovendien ooit op het bureau van de rijkscommissie werkzaam was geweest. J. L. Heldring, 'E. van Raalte', Biografisch Woordenboek van Nederland, J. Charité, ed. (Amsterdam, 1985) II, 443-444.

21 Handelingen Tweede Kamer 1966-1967, Aanhangsel 53. Luns herhaalde zijn belofte in februari 1967 naar aanleiding van een vraag van SGP-er Van Dis, die vernomen had dat de regering niet voor het jaar 2000 tot openbaarmaking wilde overgaan. Zie Ibidem, 455. 
ARP en VVD; de KVP schitterde nog steeds door afwezigheid. De druk van genoemde partijen was nu zo groot dat de regering, naar de rijkscommissie in september 1966 te horen kreeg, geen andere keus had dan te publiceren ${ }^{22}$.

Dat het om een bronnenuitgave zou gaan, stond vast. Daar hadden leden van de Eerste Kamer (Schermerhorn, Van Riel, Algra) al in 1961 om gevraagd; nu was dat verzoek in de Tweede Kamer herhaald. Bronnenuitgaven behoorden tot de grondslagen van het historisch bedrijf en tot de stiel van de rijkscommissie; in kritische bronnenuitgaven had zij haar rechtvaardiging gevonden. Daarmee stond zij in de negentiendeeeuwse positivistische traditie van historische objectiviteit, toen men meende dat alleen bronnenuitgave manipulatie van het verleden zou kunnen voorkomen ${ }^{23}$. Bronnenpublikatie bood bovendien de mogelijkheid tot een niet-archief gebonden wetenschappelijke benadering van het verleden, toetsbaar en traceerbaar voor een breder publiek. Een opdracht tot verhalende geschiedschrijving had de rijkscommissie ook nooit eerder gekregen en rekende zij niet tot haar taak ${ }^{24}$. Bij omstreden beleid leek bronnenpublikatie bovendien de meest neutrale vorm van presentatie. Beter dan via het argument zou dat verleden via de documenten zelf tot zijn recht kunnen komen, zo meende de commissie. Daarin was ten aanzien van het koloniaal verleden ook de meeste expertise opgedaan. Brugmans had in de jaren vijftig al leiding gegeven aan een bronnenpublikatie betreffende de Japanse bezetting van NederlandsIndie ${ }^{25}$. Bovendien was hij betrokken bij een serie bronnen over het koloniaal beleid in Nederlandsch-Indië 1900-1942. Deze door de Nederlandse Stichting voor Zuiver Wetenschappelijk Onderzoek (de voorloper van NWO) gefinancierde serie, ondergebracht bij het Nederlands Historisch Genootschap, was kort na de opdracht aan Boon van start gegaan. Bewerker was prof. S. L. van der Wal, eveneens voormalig ambtenaar in Nederlands-Indië en sinds 1966 hoogleraar overzeese geschiedenis te Utrecht. De eerste delen hiervan waren kort tevoren, in 1963 en 1965 , verschenen ${ }^{26}$.

Toen het kabinet-De Jong zich in 1968 dan ook mede onder invloed van een inmiddels verjongde rijkscommissie serieus bezig ging houden met de vraag hoe het de eerdere beloften kon invullen, discussieerde het slechts over de vraag wat er gepubliceerd zou moeten worden: materiaal uit de collectie-Boon die nog niet was afgerond of officiële regeringsdocumenten. Door de aan betrokkenen beloofde geheimhou-

22 F. B. M. Tangelder (secretaris rijkscommissie) aan Van Winter, 26-9-1966. ING vergaderingen RCVG Uitgaande post 1966, no 192.

23 L. J. Dorsman en E. Jonker, Anderhalve eeuw geschiedenis. (Nederlands) Historisch Genootschap 1845-1995 ('s-Gravenhage, 1995)18.

24 Notulen rijkscommissie, 28-9-1959, ING. Ook het RIOD had overigens in de lijn van die traditie materiaal over de tweede wereldoorlog via bronnenuitgaven gepubliceerd.

25 I. J. Brugmans, H. J. de Graaf, A. H. Joustra en A. G. Vromans, ed., Nederlandsch-Indië tijdens de Japanse bezetting. Gegevens en documenten over de jaren 1942-1945 (Franeker, 1960).

26 Om tegenwicht te bieden tegen een kritische Amerikaanse geschiedschrijving had men oorspronkelijk ook een Engelse vertaling beoogd. Zie ook noot 13. Omdat die te duur bleek, werden de stukken uiteindelijk alleen in het Engels aangekondigd. S. L. van der Wal, Het onderwijsbeleid in Nederlandsch-Indië 19001940. Een bronnenpublikatie (Groningen, 1963); Idem, De Volksraad en de staatkundige ontwikkeling van Nederlandsch-Indië. Een bronnenpublikatie (2 dln.; Groningen, 1965). 
ding kwam de collectie-Boon volgens de rijkscommissie niet in aanmerking. Het werk daaraan diende slechts te worden afgerond, waartoe na enig delibereren in oktober 1968 de historicus en bronnenpublicist mr. dr. C. Smit werd benoemd ${ }^{27}$. Het enige punt waar het in de nieuwe besprekingen tussen regering en rijkscommissie en binnen de ministerraad zelf om draaide, was of het om een regeringspublikatie zou gaan, een zogenaamd 'witboek' van een beperkt aantal documenten, of dat materiaal uit alle overheidsarchieven zou worden opgenomen. Omdat de regering in mei 1968 meende dat een 'witboek' levensgevaar zou kunnen opleveren voor Indonesiërs waarop zij deze vrees baseerde is niet duidelijk - , overwoog het kabinet-De Jong nog even of minister Luns de Kamer niet zou kunnen bewegen hem van zijn belofte van openbaarmaking van archiefmateriaal te ontslaan. Twee maanden en een $N R C$ artikel later achtte premier P. J. S. de Jong dat toch onhaalbaar ${ }^{28}$.

Nieuw overleg met de rijkscommissie volgde. Die bleef pal staan voor haar eisen: vrije keuze van de bewerker en toegang tot alle archieven. Alleen onder die voorwaarden was zij bereid haar wetenschappelijke verantwoordelijkheid te nemen. Een 'witboek' rekende zij niet tot haar taak. Een lid dat nog enige ongerustheid toonde over de hardheid van garanties in die richting omdat hij 'dit soort zaken [kende] van het Vaticaans archief', werd gerustgesteld ${ }^{29}$. Dankzij deze duidelijke stellingname van de rijkscommissie besloot de ministerraad in oktober 1968 tot een opdracht voor bronnenpublikatie van de officiële bescheiden betreffende de Nederlands-Indonesische betrekkingen 1945-1950 aan de rijkscommissie. Deze commissie zou de wetenschappelijke, de regering de politieke verantwoordelijkheid dragen. Een minister die ten aanzien van de archieven onder zijn beheer restricties wilde maken, diende daarvoor toestemming van de ministerraad te verwerven ${ }^{30}$. Die slotformulering bewees de verschillende visies die er in de ministerraad bestonden ten aanzien van de openbaarheid van het archiefmateriaal.

Opnieuw had het dus meer dan twee jaar geduurd voordat de in 1966 toegezegde belofte van bronnenpublikatie gerealiseerd werd. De historische traditie drukte haar stempel op de vorm. Dankzij de rijkscommissie was het een alles omvattende bronnenpublikatie geworden. Pers en politiek opteerden voor dezelfde vorm en zij wisten

27 Smit had ervaring met de publikatie van bronnen via zijn RGP-delen over de buitenlandse politiek van Nederland, met de dekolonisatie via zijn werken over de periode 1945-1949. Door een vroeger conflict met het ministerie van buitenlandse zaken over publikatie van zijn Hoogtij der neutraliteitspolitiek werd zijn benoeming vertraagd en kwam hij niet in aanmerking voor de uitgave van de bronnenpublikatie. Hij was dan ook indirect de oorzaak dat er in 1967 op dit gebied niets gebeurde. Scheiding van de twee projecten, zoals door de rijkscommissie in maart 1968 aan de regering voorgesteld, loste dit probleem op. Smit zou zijn eindverslag op 17 juni 1972 indienen. ING, D.6. Collectie-Boon; notulen rijkscommissie, 610-1967, 23-2-1968, 27-9-1968, ING.

28 Notulen ministerraad 17-5-1968; 19-7-1968, ARA. Zie NRC van 25-6-1968.

29 Notulen rijkscommissie 7-11-1968, ING. Zie voor de overwegingen van de rijkscommissie ook prof. dr. F. W. N. Hugenholtz (sinds 1968 voorzitter van de rijkscommissie) aan minister van onderwijs en wetenschappen, 23-3-1968, ING stukken vergadering RCVG 1968.

30 Notulen ministerraad 25-10-1968, ARA. 
ook nu de regering over de streep te trekken. Hueting versnelde met zijn optreden slechts de datum van de officiële opdrachtverlening. In de eerste vergadering van de ministerraad na zijn optreden, die van 24 januari 1969, werd meteen besloten dat het resterende probeem, financieel gekissebis tussen twee ministeries over een som van 20.000 gulden, snel opgelost moest worden ${ }^{31}$. Op 28 januari werd de opdracht verleend, die - zoals reeds gememoreerd - de rijkscommissie op 29 januari aanvaardde. Op 4 februari bleek de aangezochte bewerker prof. dr. S. L. van der Wal tot uitvoering bereid. Ironie der geschiedenis: in diezelfde maand verscheen deel I van het Koninkrijk der Nederlanden in de tweede wereldoorlog van dr. L. de Jong. De achterstand zou nooit meer worden ingehaald.

De twaalf jaar voorgeschiedenis van de officiële opdracht tot de bronnenpublikatie illustreert op de meest markante wijze de intense terughoudendheid van de regering om haar archieven open te stellen voor historisch onderzoek, en van participanten om daarover te spreken en te schrijven. Deze terughoudendheid heeft de bekendheid met het koloniale verleden in Nederland zeker nadelig beïnvloed. Voor hen die de jaren 1945-1949 hadden meegemaakt waren zij een persoonlijke herinnering, die verder niet getoetst kon worden aan kijkjes achter de schermen van en inzicht in het regeringsbeleid. Daar het onderwerp geen onderdeel uitmaakte van het curriculum in het onderwijs, bleven vragen van een jongere generatie achterwege. Toen het onderwerp in 1969 dankzij het optreden van dr. Hueting algemene bekendheid kreeg, viel het daardoor in het gat der onwetendheid.

Dat het bij een bronnenpublikatie bleef, was overigens niet alleen het gevolg van de historisch-wetenschappelijke traditie, maar ook van het optreden van historici zelf. Er waren immers ook andere mogelijkheden, zoals het 'RIOD-model ', waar collectievorming, bronnenpublikatie en geschiedschrijving hand in hand gingen. Naar aanleiding van het inmiddels aangevangen onderzoek naar de militaire excessen door een ambtelijke interdepartementale stuurgroep en commissie besprak de ministerraad in maart 1969 de vraag of de bronnenpublikatie niet zou moeten uitlopen in breder wetenschappelijk onderzoek. Daartoe zouden aan Van der Wal vier of vijf medewerkers moeten worden aangeboden en de hulp van enkele typistes. Ondanks bezwaren van de minister van financiën besloot de ministerraad daarover nader overleg te plegen 32. Eind maart werd Van der Wal deze mogelijkheid voorgelegd; zij kwam vervolgens ook in april in het overleg tussen prof. dr. F. W. N. Hugenholtz, sinds 1968 voorzitter van de rijkscommissie, en minister-president De Jong ter sprake. De reactie was negatief. Van der Wal wenste zich te beperken tot bronnenpublikatie en zag geen noodzaak tot uitbreiding van zijn staf, die op dat moment uit twee personen bestond. Hij vreesde — zo klonk het in de vergadering van de rijkscommissie - een uitgebreid team, dat verschillende politieke richtingen zou vertegenwoordigen: 'hij wenst een zuiver wetenschappelijke selectie uit het voorhanden materiaal ${ }^{133}$. Boven-

31 Notulen ministerraad 24-1-1969, ARA.

32 Notulen ministerraad 14-3-1969, ARA.

33 Samenvatting besprokene vergadering stuurgroep Excessennota, 2-4-1969 en 1-5-1969, Collectie Fasseur, ARA; notulen rijkscommissie 25-9-1969, ING. 
dien meende Van der Wal dat geschikte kandidaten ontbraken; scholing en opleiding van staf zou het tempo slechts vertragen. Ook Hugenholtz adviseerde - zonder overigens de rijkscommissie die slechts twee keer per jaar vergaderde, gehoord te hebben - in die richting. Zoals hij in Bijlage 15 van de Excessennota memoreerde, diende bronnenpublikatie aan geschiedschrijving vooraf te gaan.

Voorzichtigheid markeerde dus beslissingen rond vorm van presentatie van dit deel van het vaderlands verleden. Hoewel er mogelijkheden werden geboden om de bestudering breder aan te pakken, hebben historici als Van der Wal en Hugenholtz deze niet aangegrepen. Concentratie op een bronnenpublikatie sloot ook aan bij de ervaring en het karakter van Van der Wal. Hij was een zeer harde werker, een goed historicus maar een bronnenspecialist, en geen schrijver met de journalistieke vaart en verve van een Lou de Jong. Bovendien was hij zich in hoge mate bewust van het omstreden karakter van zijn onderwerp. De kritiek op het koloniale verleden stak hem. Zoals een collega bij zijn onverwachte dood in december 1978 schreef:

in een polemiek zag hij geen heil. Hierin zouden beweringen en argumentatie slechts tegenover elkaar blijven staan. Daarentegen verzamelde hij met ijver zakelijke gegevens en cijfers steunend op onaantastbaar bronnenmateriaal ${ }^{34}$.

Het feit dat hij de opdracht reeds had gekregen en aanvaard voordat van een ruimere opzet sprake was, heeft de publieke herinnering in Nederland aan de periode 19451950 mede bepaald en beperkt. Historische analyses over de periode zouden in $\mathrm{Ne}$ derland pas in de jaren tachtig verschijnen ${ }^{35}$.

De stelling 'eerst bronnenpublikatie, dan geschiedschrijving' oogstte zowel bijval als kritiek. Schermerhorn, wiens verzoek om zijn dagboek te mogen publiceren in maart 1969 door het kabinet was ingewilligd, was eveneens van mening dat bronnenpublikatie, ook van particuliere gegevens, aan geschiedschrijving vooraf moest gaan ${ }^{36}$. In het algemeen reageerde de pers neutraal of positief op de opdracht aan de rijkscommissie. Zoals na de geregelde pleidooien tot publikatie van E. van Raalte in de $N R C$ te verwachten viel, juichte deze krant dat het er nu eindelijk van gekomen was. Voor het overige nam de pers de opdracht voor kennisgeving aan. De inhoud van de 'Excessennota', die begin juni 1969 werd gepresenteerd en begin juli in de Tweede Kamer behandeld, kreeg uiteraard veel meer publieke aandacht dan Bijlage 15 (de nota-Hugenholtz), waarin een legitimatie van de bronnenpublikatie werd gegeven ${ }^{37}$.

Het enige kritische geluid inzake de opdracht was eind juni, kort voor het Kamerdebat te vinden in Vrij Nederland. Hierin bekritiseerde een zekere drs. B. B. van Dongen, historicus uit Leiden, de nota-Hugenholtz en de daarin verwoorde opzet van

34 Th. P. M. Klaus, In memoriam, BZ, februari 1979.

35 Bijvoorbeeld Jan Bank, Katholieken en de Indonesische revolutie (Baarn, 1984); J. J. P. de Jong, Diplomatie of strijd. Het Nederlands beleid tegenover de Indonesische revolutie 1945-1947 (AmsterdamMeppel, 1988); P. M. H. Groen, Marsroutes en dwaalsporen. Het Nederlands militair-strategisch beleid in Indonesië 1945-1950 ('s-Gravenhage, 1991).

36 Het Parool, 4-6-1969. Zie voor de toestemming notulen ministerraad 14-3-1969, ARA. Bewerkt door mr. dr. C. Smit zou het dagboek in 1970 verschijnen.

37 Zie de krantenknipsels in ARA, Collectie Fasseur, map 7 en 8. 
de bronnenpublikatie. Voor verantwoorde geschiedschrijving was altijd, zo stelde Van Dongen terecht, meer nodig dan een bronnenpublikatie, namelijk toegang tot het archief zelf. Gezien de omvang van het materiaal was bovendien selectie door een team van historici te verkiezen boven het eenmansbedrijf van Van der Wal. De commissie van toezicht was daarbij wel erg eenzijdig samengesteld, want zij omvatte geen leden van de 'linkerzijde' der koloniale wetenschap, zoals de Amsterdamse school van W. F. Wertheim.

De in het vooruitzicht gestelde bronnenpublicatie zal voor de leek moeilijk leesbaar zijn, voor de historicus maar weinig bruikbaar, terwijl de garantie voor de grootst mogelijke objectiviteit ontbreekt ${ }^{38}$.

Van een geschiedschrijving à la De Jongs Koninkrijk zou volgens Van Dongen dan ook voorlopig niets komen. En ook het onderzoek naar de politieke verantwoordelijkheden voor de excessen, dat in de opdracht aan Van der Wal besloten lag, zou voorlopig ook wel een vrome wens blijven. Van Dongen pleitte dan ook voor een instituut als het RIOD, zij het 'vanzelfsprekend op bescheidener schaal', waarbij publikatie en bewerking van bronnen hand in hand zouden gaan ${ }^{39}$.

Onder invloed van dit artikel kwam de bronnenpublikatie uitvoerig ter sprake bij de behandeling van de excessennota in de Tweede Kamer-waarbij overigens de ZuidCelebes-affaire algemeen afgrijzen wekte, het woord oorlogsmisdaad schitterde door afwezigheid en alle partijen strafvervolging van gedeeltelijk verjaarde misdrijven onaanvaardbaar achtten - Ook hier concentreerden de bezwaren, die uitsluitend van de oppositiepartijen kwamen, zich op het eenmanskarakter van de publikatie en de wens snel tot geschiedschrijving over de militaire en politieke context en verantwoordelijkheden van de Zuid-Celebesaffaire te komen. Moties voor een onderzoek daarnaar door een groep wetenschappers of tot een prioritering van dit onderwerp door Van der Wal, die door de PvdA, D'66, CPN en de van de KVP afgesplitste groep-Aarden werden gesteund, werden evenwel door de regeringsfracties van confessionelen en VVD, als ook door de overige partijen verworpen. Bij de verdediging van de bronnenpublikatie volgde premier De Jong de opvattingen van Van der Wal en Hugenholtz $^{40}$. Het zou dus bij bronnenpublikatie blijven. Wel werd in oktober 1969 een derde medewerker aangesteld, de net afgestudeerde dr. P. J. Drooglever ${ }^{41}$.

38 Drs. B. B. van Dongen, 'De 'excessen' in Indonesië. Kanttekeningen bij het geplande onderzoek', Vrij Nederland, 28-6-1969. Een brief van gelijke strekking had op 24 juni ook al de Tweede Kamer bereikt. Handelingen Tweede Kamer 1968-1969, 3444.

39 Handelingen Tweede Kamer 1968-1969,3562-3641,3679. De Boerenpartij nam hierbij een unieke en anti-historische positie in: zij wenste geen oude koeien uit de sloot te halen en vond elk woord over het verleden een woord te veel.

40 Het voorstel van Den Uyl om een parlementaire enquête in te stellen naar politieke en bestuurlijke verantwoordelijkheden in de Zuid-Celebes-affaire was al eerder afgestemd. Over een parlementaire enquête naar de excessen zelf en het onder ede horen van militairen werd niet gesproken.

41 Tot de staf van Van der Wal behoorden reeds mw. mr. B. van Rhijn-van Goudoever, wetenschappelijk medewerkster en mw. G. M. A. Bartstra-Rutherford Greeuw, secretaresse. De commissie van toezicht bestond uit prof. dr. F. W. N. Hugenholtz, dr. B. A. Vermaseren (directeur van het bureau der rijkscommissie), prof. dr. I. J. Brugmans en mr. A. E. M. Ribberink (algemeen rijksarchivaris). 
De opdracht tot bronnenpublikatie had overigens wel een gevolg voor de openbaarheid der archieven. Voor Van der Wal zouden deze open staan. Maar daarmee rees meteen de vraag naar de openheid voor andere historici. Ook hierin nam de regering, met name minister Luns, aanvankelijk een voorzichtig standpunt in. Voorlopig zouden de archieven slechts beperkt toegankelijk dienen te zijn voor derden, een visie die ook Van der Wal niet ongelegen kwam. Ten aanzien van dit onderwerp echter eiste de rijkscommissie meer. Zij wenste niet voor politieke doeleinden gebruikt te worden, namelijk uitsluiting van wellicht minder politiek acceptabele historici onder het mom van de bronnenpublikatie. In november 1969 stelde zij daarom het kabinet voor, dat de archieven ten behoeve van wetenschappelijk onderzoek ook voor derden toegankelijk zouden zijn, mits dezen de documenten niet integraal zouden publiceren. Het kabinet besloot in januari 1970 tot een compromis: de kwaliteit van de onderzoeker zou mede bepalend zijn voor de toestemming, dit ter beoordeling van de rijkscommissie. Minister-president De Jong ging hiermee overigens pas akkoord toen hij van Van der Wal diens instemming met het concept had vernomen. Voor De Jong ging een snelle publikatie der gegevens voor alles. De rijkscommissie zelf kon met het compromis leven; zij zou in praktijk de toepasbaarheid toetsen ${ }^{42}$.

De jaren 1969 en 1970 zijn daarmee het scharnier geworden, waarop de deur naar de archieven met betrekking tot de dekolonisatie open zou draaien. Dat was overigens het moment dat ook op andere fronten de belangstelling voor Indonesië in het algemeen en het koloniale verleden in het bijzonder in Nederland voorzichtig begon aan te trekken ${ }^{43}$. De geschiedenis van de totstandkoming van de regeringsopdracht illustreert de omslag in de publieke belangstelling echter veeleer dan dat de bronnenpublikatie daaraan direct heeft bijgedragen. Maar voordat de receptie aan de orde komt, dient eerst een korte karakterisering van de inhoud van de bronnenpublikatie gegeven te worden.

\section{De delen}

Gezien de doelstelling van de Officiële bescheiden 'een zo representatief mogelijke weerspiegeling in documenten te geven van het door de Nederlandse en NederlandsIndische regeringen gevoerde beleid', bevat de serie documenten uit de overheidsarchieven en uit particuliere archieven, voorzover van belang voor inzicht in het handelen van de overheid. Urgentie- en prioriteitsschema's van de Nederlandse en Indische regering vormden de leidraad bij de selectie. Notulen van de ministerraad en correspondentie tussen leden van de Nederlandse regering enerzijds en de luitenant-

42 Notulen rijkscommissie 25-9-1969,20-3-1970, minister van onderwijs en wetenschappen aan voorzitter rijkscommissie 18-9-1969; voorzitter rijkscommissie aan minister van onderwijs en wetenschappen 1811-1969, ING vergaderingen RCVG 1969, ingekomen en uitgaande post; minister van onderwijs en wetenschappen aan voorzitter rijkscommissie 25-2-1970, ING vergaderingen RCVG 1970 ingekomen post 46; notulen ministerraad 5-12-1969 en 9-1-1970, ARA.

43 E. Locher-Scholten, 'From urn to monument. Dutch memories of the Pacific War 1945-1995', in: M. de Keizer, ed., Memory and the Second World War (te verschijnen). 
gouverneur-generaal (H. J. van Mook), in 1948 opgevolgd door de Hoge Vertegenwoordiger van de Kroon (successievelijk Beel en H. J. Lovink), leverden de ruggegraat. Daaromheen zijn de stukken gegroepeerd die de belangrijkste politieke kwesties en de marges waarbinnen het beleid gevoerd moest worden, illustreren: kwesties zoals de geplande federale structuur van Indonesië en de Nederlands-Indonesische Unie, marges zoals die werden geboden door de Indonesische republikeinen en federalisten, door de financiën en door de houding van vreemde mogendheden. Hoewel de Officiële bescheiden als politieke serie was opgezet, is de benadering breder. De bewerkers, prof. dr. S. L. van der Wal, bijgestaan door dr. P. J. Drooglever en drs. M. J. B. Schouten (vanaf 1978), die de serie na het plotselinge heengaan van Van der Wal eind 1978 voortzetten, wensten een compleet overzicht te geven van het beleid, een algemeen beeld van de ontwikkelingen in Indonesië en Nederland en van de contacten met de meest betrokken buitenlandse mogendheden. Elk deel behandelt een periode van twee tot vier maanden, waarbij de stukken in chronologische volgorde zijn geplaatst. Via een uitgebreid systeem van verwijzingen kan de lezer de verhaallijn van afzonderlijke thema's desondanks volgen ${ }^{44}$. Hier dient tevens vermeld te worden dat de regering bij geen enkel deel gebruik heeft gemaakt van het recht om publikatie van stukken te weigeren.

De in de Kamer in juli 1969 toegezegde opzet van vier delen RGP, af te ronden in zeven jaar, bleek reeds bij publikatie van het eerste deel in 1971 niet te realiseren. Van der Wal rekende toen al op een serie van 12 tot 16 delen, in acht jaar te voltooien. Het archief bleek veel rijker dan was verwacht. Bovendien vreesde Brugmans, lid van de begeleidingscommissie, dat strengere selectie tot verwijten van overslaan van 'vervelende stukken' zou kunnen leiden ${ }^{45}$. Hoewel in 1974 reeds duidelijk was dat genoemde werkwijze tot circa twintig delen zou leiden, en begin jaren negentig zou zijn afgerond, werd dat pas na het overlijden van Van der Wal in 1978 ook openlijk erkend. Daarmee werd de door premier De Jong in 1969 in de Tweede Kamer krachtig ontkende uitspraak, dat de publikatie 25 jaar zou kosten uiteindelijk meer dan bewaarheid. Het is echter de vraag of de wetenschap daar rouwig om moet zijn.

\section{Receptie}

Want hoe zijn de negentien inmiddels verschenen delen ontvangen? We dienen daartoe onderscheid te maken in besprekingen verschenen in dag- en weekbladen en in recensies in wetenschappelijke tijdschriften ${ }^{46}$. Om met het laatste te beginnen: we-

44 Officiële bescheiden, XI, v-viii. Na het overlijden van Van der Wal werd de commissie van toezicht uitgebreid met prof. dr. H. W. von der Dunk, prof. dr. C. Fasseur en prof. dr. A. F. Manning; zittende leden waren toen prof. dr. H. Baudet (die in 1976 Brugmans was opgevolgd), prof. dr. A. Th. van Deursen (opvolger van Hugenholtz in 1977) en mr. A. E. M. Ribberink.

45 Notulen rijkscommissie, 1-5-1971, ING.

46 Het volgende stoelt op de in het ING-archief aanwezige recensies, zie ING, D. Wetenschappelijke projecten NIB 2 . 
tenschappers in binnen- en buitenland waren en zijn unaniem vol lof over deze bronnenpublikatie. De positieve reacties van internationaal bekende Indonesianisten die in hun werk kritiek op het Nederlandse kolonialisme niet schuwden, is na de Nederlandse reserves rond de bronnenpublikatie van 1969 verrassende lectuur. De grote internationale vaktijdschriften zoals de Journal of Southeast Asian Studies, Journal of Asian Studies, Pacific Affairs, The American Historical Review en The English Historical Review besteedden in hun recensiekolommen ruim aandacht aan de serie. In The English Historical Review stelde Ruth Mc Vey, onder meer bekend door haar studie van het vooroorlogse Indonesische communisme:'Van der Wal's skill in selecting and arranging his material does much to keep the narrative flowing'. M. van der Kroef noemde deel III in Pacific Affairs 'a model of careful, indeed exhaustive scholarship'; Robert van Niel, hoogleraar in Hawaii', loofde in the Journal of Southeast Asian Studies 'the care and professional detail' en voegde daar als summa cum laude aan toe 'this comes as close to perfection as anything of this sort can'. Yong Mun Cheong, die over Van Mook had gepubliceerd, prees later in hetzelfde tijdschrift Van der Wals 'painstaking labour and scholarship'. De Amerikaan John W. R. Smail achtte in het gerenommeerde The American Historical Review de eerste twee delen 'indispensable' en 'absorbing and at times exciting reading', zo ook Gerlof D. Homan later in hetzelfde tijdschrift: ('fascinating and indispensable reading'). Of bijvoorbeeld W. R. Frederick in het Journal of Asian Studies: 'a breath taking model of precision and clarity' en P. H. W. van der Veur 'a researcher's delight ${ }^{\prime 47}$. Ook de opvolgers van Van der Wal konden zich in deze kwalificaties verheugen ${ }^{48}$.

De kritiek in deze buitenlandse recensies, die voor het overige vooral op de inhoud der delen ingingen, beperkte zich in het algemeen tot het Neerlandocentrische karakter van het bronnenmateriaal, een onvermijdelijk uitvloeisel van de opdracht. Van Niel voegde daar op grond van eigen ervaring meteen aan toe dat het Indonesische materiaal of ontbrak of ontoegankelijk was ${ }^{49}$. In 1976 kon het project overigens 'one of the most ambitious documentary efforts in the field of modern Southeast Asian history' genoemd worden, een voorbeeld dat navolging verdiende van andere landen met een koloniaal verleden ${ }^{50}$.

Internationaal-wetenschappelijke erkenning is er dus voor de Officiële bescheiden volop geweest. Het is alleen jammer dat de taal de toegankelijkheid belemmert, zoals Smail al opmerkte. In hoeverre de serie in Indonesië de aandacht heeft getrokken is

\footnotetext{
47 Ruth McVey, The English Historical Review (1973) 151-153; John W. R. Smail, The American Historical Review, LXXVIII (1973) 1114; J. M. van der Kroef, Pacific Affairs, XLVII, no. 3 (1974), W. R. Frederick, Journal of Asian Studies, XXXV ( 1976) 356; R. van Niel, Journal of Southeast Asian Studies, VI (1975) 106-108; Yong Mun Cheong, Journal of Southeast Asian Studies, XIII (1982) 407-408; Idem, Ibidem, XIV (1983) 442-443.

48 Yong Mun Cheong, Journal of Southeast Asian Studies, XIV (1984) 442-443.

49 Michael van Langenberg, Review of Indonesian and Malayan Affairs, VII, no. 2 (1973) 83-89; Van der Veur, Pacific Affairs, XLVII (1974) 388-390; R. van Niel, Journal of Southeast Asian Studies, VI (1975) 106-108; Yong Mun Cheong, Journal of Southeast Asian Studies, XXI (1990) 233.

50 W. R. Frederick, Journal of Asian Studies, XXXV ( 1976) 356.
} 
niet geheel duidelijk. Het ING-archief bevat enkele artikelen in Indonesische kranten die over de inhoud van de delen verslag uitbrengen zonder daar een oordeel aan te verbinden $^{51}$.

Ook in de Nederlandse wetenschappelijke tijdschriften oogstte de serie lof. In het Tijdschrift voor geschiedenis en de Bijdragen en mededelingen betreffende de geschiedenis der Nederlanden kwamen tot nu toe alle delen aan bod. Ook hierin werd de loftrompet gestoken: 'een uiterst leesbaar, boeiend, soms zelfs fascinerend beeld'.... 'Niemand zou Van der Wal dit werk hebben kunnen verbeteren', aldus de Groningse hoogleraar H. Baudet. C. Fasseur uit Leiden achtte niet alleen het tempo imponerend, maar ook 'de rijke, in geen enkele aankondiging ook maar bij benadering samen te vatten inhoud'. Volgens zijn recensie van de delen VI en VII uit 1980 behoorde de bronnenpublikatie 'tot het belangrijkste dat in de laatste jaren in Nederland op historisch gebied' verschenen is. Ook J. M. Pluvier, leerling van W. F. Wertheim en als initiator van het Komitee Indonesië van andere politieke snit dan Van der Wal, noemde de uitgave in de Revue Belge de philologie et de l'histoire meer dan eens 'van grote waarde'. P. M. H. Groen karakteriseerde de serie als 'een fundamentele en waardevaste bron van kennis voor de Nederlands-Indonesische betrekkingen ${ }^{152}$.

De recensies in Nederlandse wetenschappelijke tijdschriften besteden evenals die in de buitenlandse vooral aandacht aan de inhoud der delen. Ook hier bleef de kritiek grosso modo beperkt tot het Nederland-centrische karakter van het materiaal. Het Brits archief, in verband met de Britse militaire aanwezigheid van belang voor de periode 1945 tot eind 1946, was echter — zoals meermalen werd gememoreerd — in de vroege jaren zeventig nog niet toegankelijk; het Indonesisch archief evenmin. Stukken uit Amerikaanse archieven werden pas in deel XII opgenomen. Vanaf dat deel werden ook meer Indonesische stukken gepubliceerd, die in Nederlandse handen waren gevallen. Baudet miste stukken over de betrokkenheid van het Nederlandse parlement. Volgens militair deskundige Groen, die de meest recente en meest uitvoerige recensie schreef, hadden de bewerkers meer stukken over militair wangedrag kunnen opnemen. Zij signaleerde eveneens dat de economische factor in de delen IX tot en met XVI buiten beeld is gebleven en de publieke opinie in Nederland en Nederlands-Indië onderbelicht.

Met haar kunnen we evenwel constateren dat sinds de verschijning van de Officiële bescheiden geen enkele studie over de Nederlandse politiek in de jaren 1945-1950, hetzij dissertatie, artikel of scriptie, om de bronnenpublikatie heen kan $^{53}$. De bronnen-

51 Bijvoorbeeld Kompas, 3-10-1974 ('studie die de volle aandacht moet hebben van degenen die belangstellen in de Indonesische geschiedenis van de revolutie'); Merdeka, 14-2-1976.

52 H. Baudet, Tijdschrift voor geschiedenis, LXXXIX (1976) 70-76; C. Fasseur, Ibidem, XC1II (1980) 678-681; J. M. Pluvier, Revue Belge de philologie el de l'histoire, LUI (1975) 618-620; P. M. H. Groen, 'Tussenbalans van een bronnenpublikatie', BMGN, CIX (1994) 17-25. Het enige Nederlandse vaktijdschrift waarin recensies schitterden door afwezigheid was de Bijdragen voor laai-, land-en volkenkunde.

53 Groen, 'Tussenbalans', 22-23. Zie ook de meest recente voorbeelden M. D. Bogaarts, De periode van het kabinet-Beel, 3 juli 1946 tot 7 augustus 1948. Nederlands-Indië. Parlementaire geschiedenis van Nederland na 1945. Band d (2 dln.; Nijmegen: Gerard Noodt Instituut 1995; P. F. Maas en J. M. M. J. 
publikatie heeft een bodem gelegd onder dit deel van het historisch bedrijf. Historici hebben hun beeld van processen in de periode bijgesteld en verfijnd, al blijven er uiteraard wetenschappelijke debatten over verschillende interpretaties bestaan. De weg naar het archief zelf is gebaand. Kortom, wanneer we afgaan op recensies en gebruik, is het wetenschappelijk succes waar de rijkscommissie in de jaren zestig op hoopte, volledig bereikt.

Wat evenwel is de bijdrage van de bronnenpublikatie aan het publieke debat geweest? Heeft de bronnenpublikatie die in 1969 als 'parlementaire bliksemafleider' diende, de openbare herinnering aan de periode 1945-1950 gestimuleerd? We kunnen er kort over zijn: hoogstens indirect via historische werken. Het is opvallend hoe weinig aandacht er in de pers is geweest voor deze uitgave. Bij het verschijnen van de eerste delen toonde de dagbladpers nog enige interesse. Het verschijnen van deel I viel samen met de reis van koningin Juliana en prins Bernhard naar Indonesië in 1971; de publikatie deelde in de hausse van belangstelling voor het koloniale verleden. Met uitzondering van De Telegraaf gaven alle grote dagbladen en vele provinciale bladen een brede beschouwing. Waarbij slechts een krant zich uitgesproken kritisch manifesteerde: de historicus J. R. Soetenhorst herhaalde in het Leidsch Dagblad de kritiek op het gebrek aan verhaal en evaluatie. En Paul van 't Veer vroeg zich in Het Parool toen al af, hoeveel delen de serie zou gaan tellen. Daarna liep de belangstelling snel terug, om in de tweede helft van de jaren tachtig een dieptepunt te bereiken.

Meestal waren het historici zoals G. J. Schutte in het gereformeerde Nederlands Dagblad en J. J. P. de Jong in de Volkskrant, of historisch actieve journalisten met aanwijsbare belangstelling voor Indië/Indonesië zoals Paul van 't Veer in Het Parool en Joop Morriën in De Waarheid, die naar aanleiding van een nieuw deel hun lezers uitgebreid over de inhoud informeerden. Van het Nederlandse krantenlezende publiek werden overigens alleen de gereformeerden en de communisten tot diep in de jaren tachtig via het Nederlands Dagblad en De Waarheid op de hoogte gehouden ${ }^{54}$. In de $N R C$ met name die indertijd zo onomwonden voor de publikatie van Indisch materiaal op de bres had gestaan, werden alleen de eerste twee delen besproken, daarna bleef elke recensie tot deel XX uit. In de jaren negentig toonde een nieuwe generatie journalisten onder invloed van de publieke debatten over het koloniale verleden opnieuw enige belangstelling, met name in de provinciale pers. Vanaf 1993 besprak bijvoorbeeld Ronald Frisait de uitgekomen delen (XVI tot en met XIX) jaarlijks uitgebreid in het Haarlems Dagblad/Leidsch Dagblad? 55.

Clerx, ed, Het kabinet Drees-Van Schaik. Koude Oorlog, dekolonisatie en integratie 1948-1951. Parlementaire geschiedenis van Nederland na 1945. Deel 3 band c (Nijmegen, 1996).

54 Als de meest trouwe recensent verdient Joop Morriën ongetwijfeld de ereprijs. Tussen 1971 en 1989 heeft hij vrijwel alle delen besproken. Schutte stopte door tijdgebrek gedwongen na de recensie van deel $\mathrm{XI}$ in 1985.

55 Zie Haarlems Dagblad/Leidsch Dagblad, 3-1 -1993,29-10-1994, 3-11 -1994, 31 -5-1995. 
Ongetwijfeld zijn er redenen voor de teruglopende belangstelling aan te wijzen. Een krant diende niet alleen een recensent te vinden die bereid was de dikke delen door te nemen maar moest daar ook overeenkomstige ruimte voor beschikbaar stellen. $\mathrm{Na}$ deel IX (1981) weigerde de Volkskrant bijvoorbeeld om een hele pagina aan dit onderwerp te besteden ${ }^{56}$. De bronnenpublikatie kon in de jaren tachtig bovendien moeilijk concurreren met de stroom van boeken die over Indië los kwam. Gemakkelijker toegankelijk voor een groot publiek, kwamen boeken eerder voor recensie in aanmerking. De serie kwam in hun schaduw te staan. Wellicht had ook het gehalte van de public relations rond de delen hoger kunnen zijn. Afgezien van een eerste persbericht in 1971 werden de delen pas sinds 1990 op die manier bekend gemaakt.

Ook al werd zij geprezen om haar leesbaarheid - Jan Blokker las de delen voor zijn toneelstuk 'Soekarno' 'met rode oortjes ${ }^{157}$ — een bronnenpublikatie is zeker geen best-seller. Terwijl van de delen van De Jong bijna 100.000 exemplaren verkocht zijn, kwam van de Officiële bescheiden een verhoudingsgewijs grote oplage van oorspronkelijk 1400 exemplaren op de markt. Conform de beperkte oplage en de beperkte publieke belangstelling speelde de serie in de debatten van 1987/1988 over de visie van Lou de Jong op het koloniale verleden dan ook geen rol $^{58}$. Alleen deel IX haalde in de zomer van 1981 hogere verkoopcijfers: van dat deel kwam zelfs een stapel in de Bijenkorf te Amsterdam te liggen. Een haastig lezende journalist had in dat deel het bewijs gevonden dat de legertop in juni 1947 Schermerhom had willen liquideren. Stof dus voor een fraai schandaal, dat vele kranten in de zomerse komkommertijd overnamen. Helaas zoals vaker in de Nederlandse geschiedenis waren de feiten braven admiraal Pinke bedoelde slechts de liquidatie van hetkoninkrijksverband $^{59}$.

Samenvattend kunnen we concluderen dat de Officiële bescheiden de historische wetenschap hebben gediend en geschraagd. Conform aard en karakter van deze vorm van historische representatie is haar uitstraling echter beperkt gebleven. Alleen indirect, als basis voor historische publikaties, heeft zij bijgedragen aan vergroting van de kennis van dit deel van het koloniale verleden van Nederland.

\section{Conclusie}

Hiermee is de vraag naar het waarom van een bronnenpublikatie voor de periode

56 J. J. P. de Jong, mondeling 21-2-1996.

57 De Volkskrant, 24-11-1995.

58 Volgens De Telegraafvan 11 -2-1988 was De Jong door de bronnenpublikatie afgetroefd, want die had de nieuwste documenten.

59 De gewraakte zin in de brief van A. S. Pinke (commandant zeemacht) aan C. E. L. Helfrich (bevelhebber der zeestrijdkrachten) luidde: 'Dus Schermerhom staat afwijzend tegenover geweld en dan zou er niet anders op moeten zitten als liquideren! Want geven wij weer toe, dan wordt het liquideren, daar kunt U zeker van zijn. Ik hoop nog altijd dat de Ned. Regering dit voorkomt'. Officiële bescheiden, IX (1981) 385 . Zie voor het bericht Utrechts Nieuwsblad, Leeuwarder Courant, Nieuwsblad van het Noorden, 25-7-1981. Terwijl de laatste krant op 30-7-1981 een correctie publiceerde, verwerkte het Vrije Volk een dag later het bericht nogmaals. 
1945-1950 en het daarmee samenhangende verschil in bekendheid tussen de perioden 1940-1945 en 1945-1950 beantwoord. Er valt een rechte lijn te trekken van de koloniale strijd naar omstreden verleden en van daarmee samenhangende geheimhouding van overheidswege naar deze Officiële bescheiden. Het is echter de vraag of we de voorgeschiedenis van en uiteindelijke keuze voor een bronnenpublikatie moeten zien als signaal van koloniaal trauma. Chronologisch passen zij in de periode van nationaal zwijgen over het koloniale verleden. De ervaringen kunnen zeker voor betrokken politici traumatisch zijn geweest. Het hier behandelde maakt echter duidelijk dat het spreken in sociaal-psychologische termen van trauma en verwerking over het Nederlands verleden gekenmerkt wordt door een hoog metaforisch gehalte 60.Het trauma was niets anders dan een politieke strijd om de koloniale herinnering en geschiedschrijving. Zoals minister Luns in de jaren vijftig en zestig het Indonesië-beleid domineerde, zo hield hij, gesteund door collega's in de kabinetten waarvan hij deel uitmaakte, de archieven gesloten. Totdat hij tenslotte ruimte bood voor de neutraal geachte vorm van een bronnenpublikatie, die historici hadden voorgesteld en waar de 'historische lobby' in pers en parlement op had aangedrongen.

Historici hebben overigens niet alleen de vorm bepaald maar ook hun stempel gedrukt op de receptie van de Officiële bescheiden. Als recensent vertaalden zij de inhoud van de bronnenpublikatie voor een groter publiek, mits zij daaraan tijd en de kranten daaraan ruimte wilden besteden. In de jaren zeventig deelden de eerste delen nog in de hernieuwde belangstelling voor het koloniaal verleden, in de jaren tachtig werd de serie vooral slachtoffer van de nieuwe boeken-hausse; onder invloed van de debatten over de dekolonisatie naar aanleiding van 'Poncke' Princen in de jaren negentig kwamen zij voorzichtig terug in de zijlijn van de provinciale pers.

Wat nu te doen? Is het tijd voor een nieuwe Rijksgeschiedschrijver die de geschiedenis van de Indonesische revolutie en de dekolonisatie in de jaren 1945-1950 in verhalende vorm neerzet, zoals Den Uyl nog in 1987 bepleitte $^{61}$ ? Die oplossing lijkt me in onze post-moderne tijd achterhaald. Meer nog dan tevoren is de geschiedwetenschap doordrongen van de 'gesitueerdheid' van alle historische kennis. Bovendien heeft het weinig zin de waarde van bronnenpublikaties over de dekolonisatie te ontkennen. Niet alleen heeft deze Nederlandse serie in wetenschappelijke kring nationaal en internationaal hoge ogen gegooid, de vorm als zodanig heeft internationaal op dit moment niet over gebrek aan belangstelling te klagen. Afgezien van de vijfdelige (niet afgeronde) Britse serie over de dekolonisatie van India uit het begin van de jaren zeventig en enkele veel kleinere, tweedelige werken uit de jaren tachtig, is men

60 Zie ook Locher-Scholten, 'Verwerking en koloniaal trauma'.

61 In maart 1987 vroeg $S$. den Uyl, of het, nu de bronnenpublikatie ver gevorderd was, niet tijd werd voor een regeringsopdracht tot officieel historisch onderzoek. Premier R. Lubbers antwoordde ontkennend. De regering kon slechts voorwaarden scheppen voor wetenschappelijk onderzoek en slechts bij hoge uitzondering zoals de opdracht aan dr. L. de Jong een staatsopdracht verlenen. Omdat elke historische visie gekleurd was, kon zij zich niet daaraan binden. In februari 1988 herhaalde Lubbers dit standpunt in antwoord op kamervragen van PPR en PSP over een eventueel te herzien oordeel over de Excessennota. Handelingen Tweede Kamer 1987-1988. 
in Groot-Brittannië pas sinds 1987 bezig met een grootschalig project Documents on British policy overseas over de periode 1945-1957. Hierin zijn behalve delen over het algemene regeringsbeleid ook delen over de verschillende koloniën opgenomen. Ook de Franse dekolonisatie, die qua regio (Indo-China) en qua trauma (Algiers) het meest met de Nederlandse ervaringen valt te vergelijken, vindt pas sinds eind jaren tachtig haar weerslag in twee, nog weinig gevorderde series bronnen ${ }^{62}$.

Nodig is verdere geschiedschrijving en vooral popularisering van de kennis die in de twintig delen Officiële bescheiden en de archieven zelf liggen opgeslagen. De bronnenpublikatie is als een toegankelijk park, of om in Nederlandse termen te blijven als een natuurreservaat. De archief-wildernis is gedeeltelijk ontgonnen, de boomsoorten zijn onderscheiden, de paden aangeharkt, de uitzichten verzorgd. Buiten lokt de wildernis voor wie nieuwsgierig gemaakt verder wil. Door herkenningspunten vanuit het park en kaarten in de vorm van inventarissen is het papieren oerwoud nu ook beter toegankelijk.

Nodig zijn ook verdere verkenningen daarvan èn van Indonesisch, Brits en Amerikaans materiaal. Het debat over de resultaten van ontdekkingstochten in bronnenpublikatie en archief dient te worden voortgezet. Elke groepering heeft daarbij zijn professionele taak en verantwoordelijkheid. De historicus zal onderzoeken, publiceren en doceren, de journalist populariseren. Het onderwijs kan de basis leggen onder alle toekomstige activiteiten door van een jongere generatie aandacht te vragen voor dit deel van het Nederlands verleden. Want zonder een begin van kennis is in het algemeen weinig historische interesse te verwachten en zullen de politieke debatten over de dekolonisatie van Indonesië zich als repeterende breuken door de toekomst doen horen. Terugkerend tot ons motto: 'Wat voorbij is, gaat niet meer over'. Dit geldt zeker voor de geschiedenis van de dekolonisatie van Indonesië en het Nederlandse aandeel daarin. We hebben een koloniaal verleden en zullen dat weten ook.

62 N. Mansergh en E. W. R. Lumby/P. Moon, ed., Constitutional relations between Britain and India. The transfer of power 1942-1947 (5 din.; Londen, 1970-1974); Hugh Tinker, ed., Constitutional relations between Britain and Birma. The struggle for independence 1944-1948 (2 din.; Londen, 1983-1984); A. N. Porter en A. J. Stockwell, British imperial policy and decolonisation 1938-1964 (2 din.; Londen, 19871989); S. R. Ashton en D. R. Low, ed., British Documents on the end of Empire (Londen, 1987...). Voor Frankrijk: G. Bodinier, ed., La guerre d'Indochine 1945-1954. Textes et documents, I, Le retour de la France en Indochine 1945-1947 (Vincennes, 1987); II, Indochine 1947. Règlement politique ou solution militaire (Vincennes, 1987); J. C. Jauffret, La guerre d'Algérie par les documents, I, L'avertissement 1943-1946 (Vincennes, 1990). 


\section{De oorlog op herhaling: recente literatuur over de Duitse bezetting van Nederland}

\section{MARTON VAN HENN1K}

De stroom publikaties over de Duitse bezetting van Nederland in het vijftigste herdenkingsjaar heeft die van eerdere jaren in omvang overtroffen. De aanwinstenlijst van de bibliotheek van het Rijksinstituut voor oorlogsdocumentatie over het jaar 1995 telde ruim 220 titels over dit onderwerp. Vooral het aantal lokale studies bereikte een hoogtepunt: bijna 100. De publieke belangstelling voor de bezetting was groter dan ooit tevoren. De strijd tegen en de collaboratie met het nationaal-socialistische Duitsland, dat het Nederlandse volk in 1940 van zijn vrijheid beroofde, leek deze belangstelling ook in 1995 te beheersen. Nog altijd worden uit deze periode lessen getrokken om morele en politieke standpunten te legitimeren. In dit artikel wordt een aantal in 1995 verschenen publikaties over de Duitse bezetting van Nederland en de tweede wereldoorlog, verdeeld over een achttal thema's, besproken.

\section{Voorbij goed en fout?}

Het 'zingevend perspectief' dat J. C. H. Blom in 1983 signaleerde, bepaalde ook in 1995 voor het grootste deel het beeld van de bezetting 1 . Dit perspectief, waarin de strijd tussen het nationaal-socialisme en zijn tegenstanders centraal staat, had en heeft nog steeds een sterk politiek-morele lading. De bijzondere rechtspleging in de eerste na-oorlogse jaren wettigde een algemene consensus over een tweedeling van het Nederlandse volk in 'goed en fout', die tijdens de oorlogsjaren was ontstaan. Deze consensus bepaalde in hoge mate de wijze waarop Nederland zich rekenschap gaf van het oorlogsverleden. Maar het publieke debat, waartoe ook het werk van historici gerekend kan worden, wenste de vraag over goed en fout niet slechts op juridische gronden te beantwoorden. Het gedrag van Nederlanders tijdens de bezetting werd ook langs een morele meetlat gehouden.

Collaboratie en verzet, en sinds het eind van de jaren zestig door de aandacht voor de jodenvervolging in de belangstelling geraakte thema's als aanpassing en passiviteit gaven vorm aan een beeld van het oorlogsverleden, waarin de lotgevallen van de Nederlandse bevolking in het middelpunt staan. Aan de totstandkoming van dit beeld heeft het werk van L. de Jong in belangrijke mate bijgedragen. Maar ook na voltooiing van de eerste tien delen van L. de Jongs Het koninkrijk der Nederlanden in de tweede wereldoorlog bleef bovengenoemd perspectief het beeld dat van de bezetting werd geconstrueerd in sterke mate beïnvloeden. Bloms constatering dat 'men kan zeggen, dat met de voltooiing van het werk van De Jong een fase in de geschiedschrijving

1 J. C. H. Blom, 'In de ban van goed en fout? Wetenschappelijke geschiedschrijving over de bezettingstijd in Nederland', herdrukt in: G. Abma, Y. Kuiper, J. Rypkema, ed.,Tussen goed en fout. Nieuwe gezichtspunten in de geschiedschrijving 1940-1945 (Franeker, 1986) 32. 